Article

\title{
Enclaving the City; New Models of Containing the Urban Populations: A Case Study of Cairo
}

\author{
Safa H. Ashoub ${ }^{1, *}$ and Mohamed W. ElKhateeb ${ }^{2}$ \\ ${ }^{1}$ Chair for Urban Design and Urbanisation, TU Berlin, 10623 Berlin, Germany; E-Mail: safa.ashoub@campus.tu-berlin.de \\ 2 Independent Researcher, Germany; E-Mail: mwkhateeb@gmail.com \\ * Corresponding author
}

Submitted: 30 November 2020 | Accepted: 25 March 2021 | Published: 25 May 2021

\begin{abstract}
This article builds on theoretical foundations from enclave urbanism, authoritarian planning and neoliberal urbanisation to explore contemporary socio-spatial transformation(s) happening in Cairo, Egypt. Relying on a nationwide road development project, inner-city neighbourhoods in Cairo are turning into urban enclaves, whereby populations are being separated by a multiplicity of transport-related infrastructure projects. As these rapid planning processes are occurring, our article aims to explain why these developments are crucial and unique in the context of the post-Arab Spring cities. We argue that the new road infrastructure is creating a spatially and socially fragmented city and transforming the urban citizenry into a controllable and navigable body. We use an inductive approach to investigate the effects of the new road infrastructure and its hegemonic outcomes on the city. On a conceptual level, we propose that the enclaving of the city is a containment method that has erupted since the mass mobilisations of the Arab Spring. In doing so, we use qualitative analysis to explain empirical evidence showing how the city is being transformed into nodes of enclaves, where communities are getting separated from one another via socio-spatial fault lines.
\end{abstract}

\section{Keywords}

Cairo; containment; fragmentation; mobilisation; road infrastructure; socio-spatial transformation; urban enclaves

\section{Issue}

This article is part of the issue "Planning for Rapid Change in Cities" edited by Karina Landman (University of Pretoria, South Africa).

(C) 2021 by the authors; licensee Cogitatio (Lisbon, Portugal). This article is licensed under a Creative Commons Attribution 4.0 International License (CC BY).

\section{Introduction}

Since 2011, Cairo has undergone multiple changes. The global economic situation has affected Cairo, like other cities, by causing further segregation on social, economic and spatial levels. The new Egypt that emerged post-2014 was the result of a forceful and intimidating reassertion of military power evident at every level. It could be noticed through the expansion of military services to include the selling of day-to-day products and dominating the urban development scene. The most common driver for such changes, based on literature and widespread observations, is a belief among the political elite that Egypt needs to reinvent itself to absorb the 2011 political and socioeconomic shock and to re-emerge as a new state, with a readjusted self-image to fit into regional and global contexts (Roll, 2014).

Cairo has long been an exhaustively studied city of the Middle East-North African region, yet its rapid changes continue to force researchers to reinvestigate and reassess its complexity. This article attempts to comprehend the logic of a city that has-seeminglyspiralled out of control (Sims, 2012) and has experienced continuous change since 2011 . Yet, it is proving again to be indeed excessively controlled.

In 2011 and afterwards, we witnessed the reemergence of citizen engagement and, to a certain extent, a sort of urban activism, using mainly the (right to the city) as an umbrella discourse to claim most of the restricted civil rights, focusing on the immediate 
urban needs as a starting point. Such a development has meant that many of the middle-class citizens became engaged in one way or another in the revolutionary claims for bread, freedom and social justice of the 2011 Egyptian uprising, and moved beyond them in reshaping the public-private spheres (Rennick, 2013). This has posed a challenge to policymakers and power circles; whereby new segments of the population became engaged and politically mobilised and thus should be contained. Especially working-class citizenry was used to utilising hide-and-seek tactics with the previous regime. Also, there was a fairly large segment of society that had no stance towards much of the uprising and preferred to 'sit and watch,' which led to considerable ambiguity in predicting their behaviour. In conclusion, the contemporary Egyptian middle-class as a social group has posed puzzling characteristics to the current ruling regime. On many occasions, this large and heterogeneous group has remained latent and in other moments displayed volatility in post-revolutionary times (Abaza, 2014; Sallam, 2013).

The Cairo 2050 plan was intended to be implemented in 2008-2010, but the active engagement of citizens and urbanists since the revolution has led to the project's delay (Reeve, 2011). By 2014, the New Administrative Capital (NAC; see Elmouelhi, 2019) project became known to the public as the new national project for moving the capital to the east-i.e., into the desert (Figure 1). The NAC is the epitome of the current regime's mindset. It represents and embodies all the aspirationsand often the insecurities-of Egypt's new ruling elite. Between the NAC and the old neighbourhoods of Cairo, the urban contrast is too powerful to ignore. Where there is a city, there is its anti-city (Lindsey, 2017). According to some statistics, it is estimated that $60 \%$ of Cairo's existing built environment is considered informal or partially illegal development, i.e., only $40 \%$ is considered formal or fully licensed development (Tadamun, 2014). This leaves most Cairenes to struggle daily simply to move around in such a complex built environment.
In the past couple of years, some research has investigated the reasons behind and the potential effects of the construction of the NAC (Elmouelhi, 2019; Kingsley, 2015) as Cairo's main urban-planning endeavour-and the role of the ruling regime as the main stakeholder. Nonetheless, this article is concerned with the urban transformation of Heliopolis, one of the upper and middle-class neighbourhoods in East Cairo (Figure 2).

The neighbourhood of Heliopolis (Masr El Gedida, which translated from the Arabic means 'new Egypt') is a neighbourhood built in the 20th century by the Belgian Baron, Édouard Empain ("How Cairo's Heliopolis heritage managed to remain uncovered," 2021). Originally a middle-class suburb, it became the seat of the Egyptian Presidency in the 1970s as well as other important state bodies (Presidency, n.d.); the military academy and other armed forces facilities are also located there (Agence France-Presse, 2020). It is well known for its unique urban heritage, characterised by French-style avenues and Islamic-style buildings ("How Cairo's Heliopolis heritage managed to remain uncovered," 2021). In this article, we refer to old neighbourhoods of Cairo as city quarters that were developed in the late 19th and 20th centuries (Abu-Lughod \& AlSayyad, 2020). Heliopolis and downtown Cairo have been part of the political centre since the 1980s. The Ittihadeya ('federal') Palace (Figure 3) had previously been an abandoned hotelthe Grand Heliopolis Hotel-designed by the Belgian architect Ernest Jaspar and opened in 1910 (interview with A. M., who wrote his master's thesis thoroughly on Heliopolis). In 1972, it became the headquarters of the Federation of Arab Republics, a loose political confederation that included, at that time, Egypt, Syria and Libya. Later, the palace became the Egyptian Presidential Headquarters after Mubarak became president in the 1980s (Presidency, n.d).

In that regard, the importance of Heliopolis arises from its heavy share of the political and urban history of the city (Zaineldine, 2020), including its colonial and post-colonial roots. This article describes and analyses

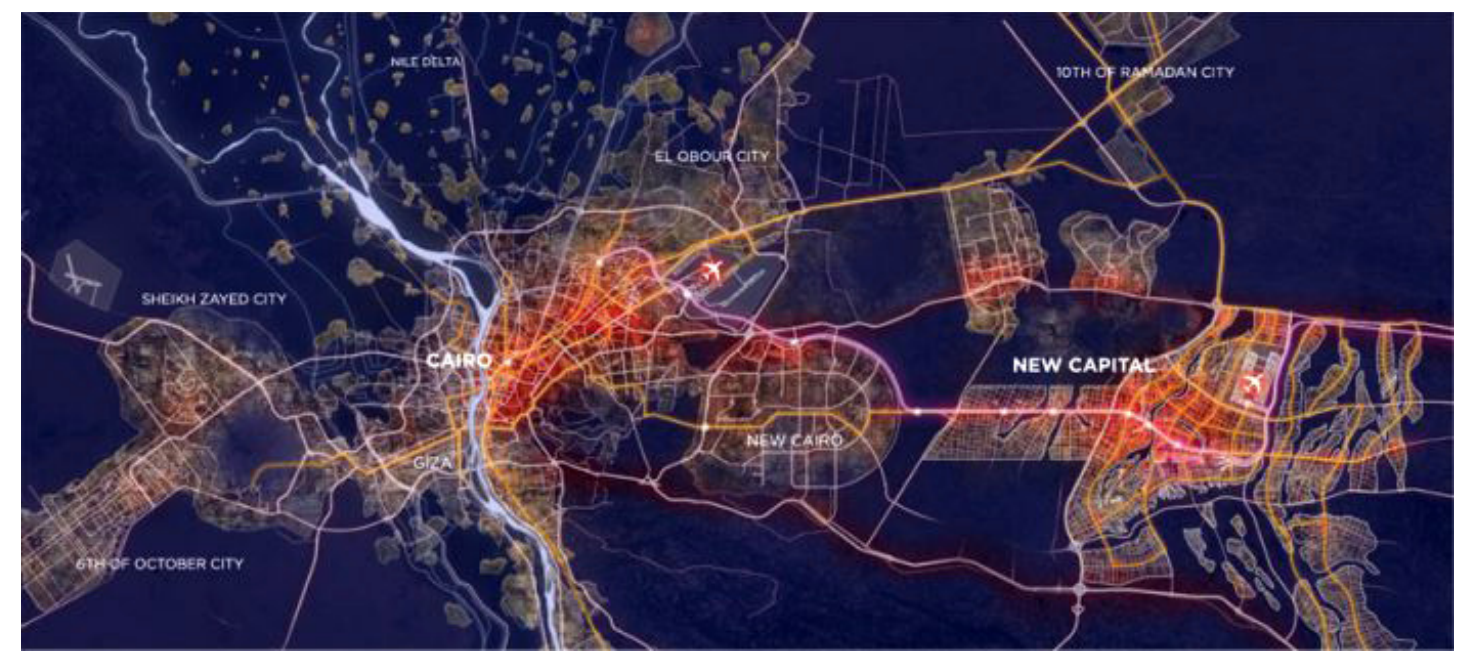

Figure 1. The NAC location. Source: Frearson (2015). 


\section{COGITATIO}

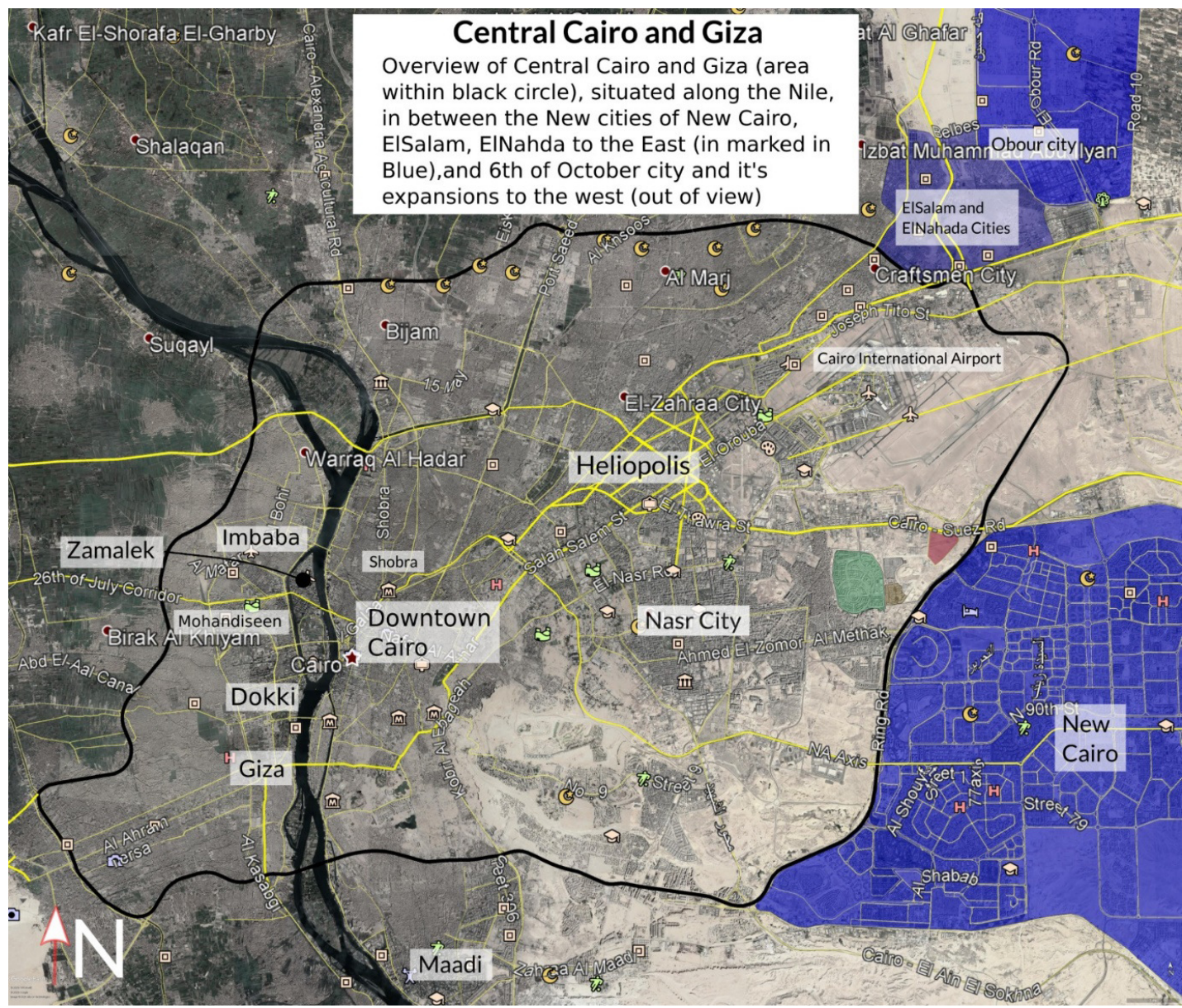

Figure 2. Central Cairo. Source: Map developed by M. W. ElKhateeb for this article based on Google Earth Pro based map.

the changes that have come about to the neighbourhood under the current regime. We focus on the processes of urban transformation especially in the formation of urban enclaves and their effects on the neighbourhood and eastern Cairo. This in turn led us to tackle the issues of socio-spatial fragmentation of the middle class(es) in that context. The rapid planning and execution of these new urban interventions have been a cause for suspicion and worry to planners and observers. Therefore, we embarked on this article in an attempt to explain and

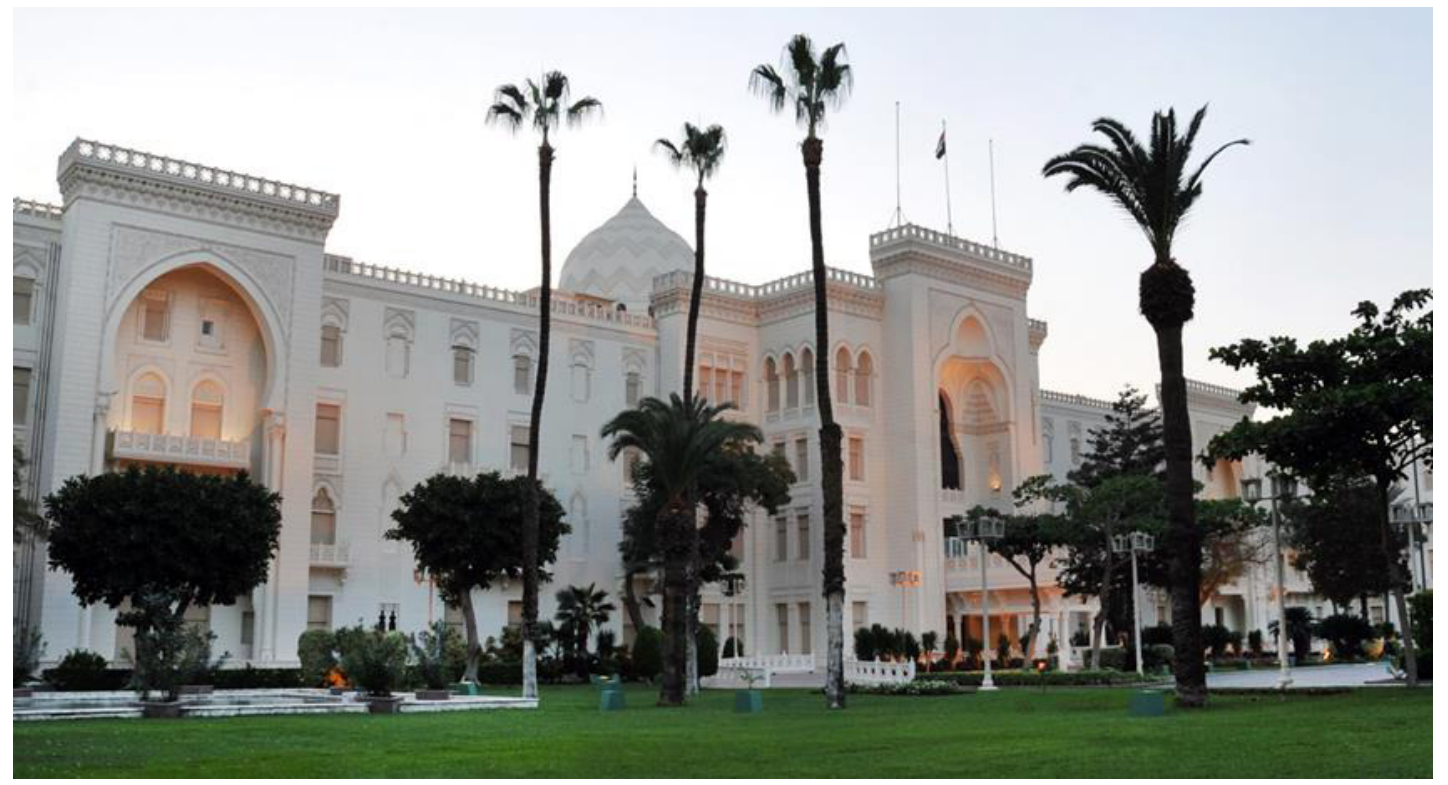

Figure 3. The Ittihadeya Palace (Grand Heliopolis Hotel). Source: Presidency (n.d). 
contextualise the regime's tools in containing urban populations post-2011 uprising.

\section{Notes on Methodology}

This research article was first conceptualised in the Spring of 2020; the writing started in Autumn 2020 and was completed in the Spring of 2021, in Cairo, Berlin and Freiburg. The fieldwork took place in Cairo and was very difficult and intensive, especially in terms of interrupted data collection (due to Covid-19 restrictions) as well as in keeping up with the rapid changes that consistently occurred in the case study area. That demanded finding a balance between being flexible but also consistent in approaching our case study. The choice of the case study was based on previous research phases and as part of our larger research interests, whereby we deliberately chose to look into the urban life of the (upper) middleclass neighbourhoods of Cairo. In this article, we refer to the 'middle class' as white-collar citizens with universitylevel education and professional jobs (Burris, 1986).

As for our positionality, we identify ourselves as middle-class researchers (male and female; see Burris, 1986), with Western education(s) and living between home and abroad (Throne, 2012, pp. 55-77). We look into issues of urban contestation as both inhabitants and researchers. Since we experience the city ourselves, we did not disconnect our observations from the empirical data sources on which we relied; instead, we combined them to produce an auto/ethnographic analysis (Qutoshi, 2015). As qualitative researchers, we used an inductive-grounded theory approach (Pulla, 2014), using primary and secondary resources to reach an answer to our hypothesis.

For the primary data, the methods used for data collection were comprised of an online survey, semistructured interviews and ethnographic observation(s). The period of data collection was from July to November 2020, with some additions in February 2021. Earlier exploratory research such as informal interviews and observation had taken place in January 2020. The survey was administered between September and November 2020 using online tools (Google Forms) and was placed publicly on social media (Facebook), which yielded 32 respondents in total. This methodology has been repeatedly used by researchers with numerous positive and negative results (Lehdonvirta, Oksanen, Räsänen, \& Blank, 2020). We chose this method due to its convenience in reaching out to respondents from the case study area, especially due to Covid-19 restrictions. We also used the data gathered as an indicative outcome about trends. We did not intend to use it as a quantitative instrument, but rather as a tool to give us direction about what the respondents were experiencing. We acknowledge that access to the internet is a limitation in the search for survey participants, which was further compounded by the Covid-19 shutdown of public life. That is why we used the virtual space as an alter- native medium for gathering primary data. We followed and observed citizen interactions on social media pages discussing the changes happening to the different neighbourhoods of Cairo. This is considered an experimental method in social sciences, but has been particularly important for our case study since 'virtual urban contestation' has become one of the few alternatives for citizens' engagement in urban and political affairs in Cairo, especially after the 2014 closure of public life (Abaza, 2012; AlSayyad \& Guvenc, 2015).

For the semi-structured interviews, we conducted seven key informant interviews, with a purposive sampling approach (Suri, 2011) to talk to some of the most knowledgeable persons for our chosen case study. In that regard, we spoke to three members who had previous or on-going institutional relationships (founders) with the Heliopolis Heritage Foundation, as well as two non-active members (professional urban photographers-in addition to their original professions), and two individuals who had lived in Heliopolis neighbourhood for a long time (one of them lived there for 40 years, from the 1960 s to the 2010s). These interviews took place in January 2020 (with respondents T. S., K. A. and M. H.), in August 2020 (with respondent K. B.), in September 2020 (with respondent A. D.) and in January 2021 (with respondents $A$. M. and A. Z.) respectively.

For the secondary data, we conducted a literature review (including newspaper articles) relevant to the case study, from July 2019 to November 2020.

The data analysis relied on content analysis as we navigated through literature and complemented it with our findings from the survey, interviews, field observations and ethnographic work, to gain an in-depth understanding of the subject at hand (Baur, 2019; Qutoshi, 2015). A lot of the data was obtained from internet sources, specifically from social media outlets. Facebook pages had the largest share of content due to the predominance of pages that tackled local urban issues. The virtual nature of social media platforms allowed us to collect enormous amounts of data, which were later screened based on necessity, importance and relevance for the research. A sample of the observed pages include the Facebook pages for the "Heliopolis Heritage Initiative," the "Heliopolis Chronicles," the "Heliopolisawy Citizen," the "We Grew Up in Heliopolis Public Group," the "Heliopolis Citizens Complaints' Group," "WhatsUp in Heliopolis and Nasr City," among others. Also, there were groups based on mobile phone applications, for example, a WhatsApp group for Heliopolis residents' complaints and a similar one on Telegram.

The key limitation of this research was the spread of Covid-19 globally, especially in the EU, where both researchers are based, as well as in Egypt where the case study is situated. That added challenges and limitations to the research in terms of field data collection and ease of access to interviewees. In addition, issues of security arose during fieldwork, whereby our research team had 
to be extra careful during field observation and photography due to the heightened security in the neighbourhood of Heliopolis.

In terms of research ethics and confidentiality, the online survey had a statement on the purpose of the research and was left for voluntary participation (on the condition of being a resident of the neighbourhood). For the key informant interviews, all participants gave verbal consent to mentioning their names openly in the research; however, we chose to keep them anonymised and only refer to their initials, for extra vigilance. For social media sources, all personal information was anonymised.

\section{Research Framework}

The research framework relied on readings on authoritarian urbanism (Luger, 2016), neoliberal urbanism (Abaza, 2020; Adham, 2005; Daher, 2013; Harvey, 2005), urban enclaves and segregation (Caldeira, 1996; Calvet, 2016; Roitman, 2010) and global urbanism (Robinson \& Roy, 2016) to frame the socio-spatial transformation occurring in the chosen case study. We also explored some literature on military urbanism (Abaza, 2020; Flahive, 2018), urban politics (Saunders, 1986), and Southern urbanism (Bhan, 2019). Through the literature review, we formulated the key hypothesis for this article, asking how the process of creating inner-city urban enclaves could be considered as an approach to contain post-revolutionary cities and to diffuse any potential public mobilisation (Abaza, 2014). This led us to review more literature on 'urban diffusion' as proposed by Adham (2014), to understand from where the urban visions of Cairo have emerged in the past decade, as well as to explore the literature on urban enclaves and road infrastructure as forms of political control. The process of forming enclaves within the inner city (through the construction of roads, fences, bridges, other types of physical barriers, etc.) and at the outer city (as gated communi- ties and high-end exclusive compounds in suburbia) suggest that these developments are models of containing the Cairene population, especially the upper and middle class(es). Hence, it is evident that there is a deliberate effort to segregate, fragment and control the city and its urban population(s).

The discourse of Egypt's post-revolution ruling elite strongly emphasises transforming Cairo into a Global City (Adham, 2005; Robinson \& Roy, 2016). Global Cities are the primary neoliberal centres of economic transactions, and competitiveness lies at their core, and thus expanding urban services and logistics is one of their dominant characteristics. However, the notion of Global Cities has been criticised for homogenising cultures, commercialising the urban, and overlooking the human as a scale for development (Lefebvre, Elden, \& Brenner, 2009). Egypt's ruling elite, nonetheless, have adopted a belief after the revolution (or even shortly before) that the country has fallen behind in terms of global competitiveness and should therefore come back and place itself at the forefront of the Arab and African nations as a regional key player. In policy circles, those beliefs were translated into the infamous plan of Cairo 2050 (or Cairo 2052, as it was delayed by two years in 2010 , due to the uprising; see Flahive, 2018), as shown in Figure 4 . The 2050 plan proposed a radical makeover for the city and stressed the widening of the roads and creating Champs-Elyseésinspired boulevards as part of a vision that aims to spatially reorganise the ailing capital to become more appealing to a global clientele (Reeve, 2011). As Adham explains, such a vision has erupted from a long process of exporting a Gulf urban model to Egypt, both culturally and politically.

This comes, of course, at the expense of the citizenry, as became evident in several forced evictions in several cases in downtown Cairo, intending to recapture land value by instrumentalising the rhetoric of informality as well as by dislocating the poor from the central parts of the city (Adham, 2014). Therefore, the

\section{Cairo Vision 2050 Cairo: Global - Green - Connected}

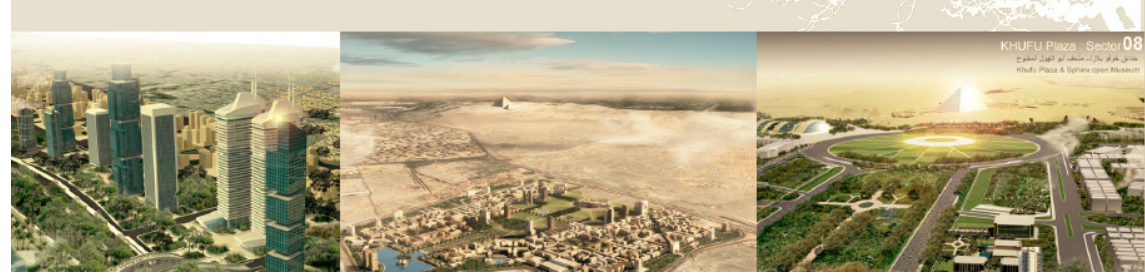

Figure 4. Cairo as a Global City. Source: General Organisation of Physical Planning and Ministry of Housing (2010). 
widening of streets is not a new endeavour for Egyptian policymakers -it is part of a larger vision of "transforming the old city into one big flyover heading towards the new administrative capital" (as stated by A. Z. in an interview). This comes in parallel to transportation policies that favour motorised-private vehicle ownership versus shared and greener options for transport (El-Dorghamy, Allam, Al-Abyad, \& Gasnier, 2015; Reeve, 2011).

\section{Producing Urban Enclaves}

Enclaves are more than fences. As an urban construct, enclaves are designed to control yet also give a sense of privilege to their direct subjects. This separation is complemented by emphasising the spatial and aesthetic features of each area concerning other adjacent areas. Gated communities thrive on social homogeneity, highend amenities, a common aesthetic reference, and a strong legal code to protect all of these (Atkinson \& Ho, 2019). This mode of production of socio-political space (Elden, 2007; Löw \& Goodwin, 2016) is uniquely designed to ensure that (upper) middle-class populations are spatially disconnected and made suspicious about the 'unfamiliar city,' and so remain controlled in some way. As this disconnection happens, their positionality within the city changes and the new spatial order dictates which parts of the city are to be included in their navigation; only those deemed as both safe and socially appealing. From the works of Caldeira (1996), we notice that there is an emphasis on the notion of (a self-contained world) in the formation of the enclaves, which refers to the ability of the enclave residents to isolate themselves from the public life outside the fences of their condominium (Perry, 2000).

In other words, urban enclaves (and gated communities) have a clear distinction between the exclusive (safe) space and the shared (unsafe) space. Also, they are mostly occupied by the more affluent segments of the population. They cater to the exclusivist needs of the elite (Hashemi, 2019; Nielsen, Sumich, \& Bertelsen, 2020; Sumich, 2016). Needless to say, this resonates well with the economic interests of the ever-growing real estate industry. Such a phenomenon is not new to the world; these enclaves have been shaped and reshaped to offer new neoliberal urban spaces (Adham, 2005; Daher, 2013; Harvey, 2005) as the grasp of capital tightens. This is described by Calvet $(2016$, p. 5) as:

Urban enclaves-private and gated developments for elitist groups-are a worldwide-spread mode of colonisation of the peri-urban and countryside of metropolitan areas, in a context of cities under capitalist globalisation and urban neo-liberalisation.

These notions brought us to sub-questions that built on our initial reading to the production of urban enclaves in the Egyptian context. Firstly, how do we understand the relation between enclaving, security and aesthetics?
Secondly, how does segregation ensure the overall containment of a city?

Against this theoretical backdrop, the next part presents the analysis from our fieldwork, where we tackled the execution of the new urban interventions in the neighbourhoods of East Cairo, particularly in Heliopolis. We investigated the process and the consequences of the development of new (wider) roads, the construction of a series of flyovers (bridges) and the sizable reduction of sidewalks and green spaces. We also looked into the new vacant spaces and how inner-city enclaves have been produced.

\subsection{Material Constructions/Obstructions and Spatial Grievances}

We conceive of the inner-city neighbourhoods as enclaves, only after they are transformed as a product of the new road and transport infrastructure intervention. In this regard, we define them as areas of the old city neighbourhoods that have long existed yet became transformed into segments of spaces that have sharp edges further dissected by roads and traffic corridors to separate their boundaries. Their boundaries appear to be ambiguous, producing a space that is uncontentious. By uncontentious, we mean a space that has no clear ownership (No-Man's Land). For example, ambiguous spaces are found underneath a bridge, or along a concrete wall, or on a highway (Figure 5). Enclaves, then, are constructed by a deliberate effort to draw fault lines between suburbs and neighbourhoods, with clear buffer zones of roads, bridges, vacant spaces and fences (Hashemi, 2019; Nielsen et al., 2020; Wang \& $\mathrm{He}, 2019$ ).

As we gathered evidence from our empirical work, we observed an astonishing decline in the aesthetic quality in the Heliopolis neighbourhood. From the interviews, survey and social media observations, one strong recurrent statement was that the neighbourhood was in a state of decay despite the new street upgrades. Namely, the quantity and quality of green spaces had shrunk, the quality of sidewalks had become very poor, the pedestrian space (and safety) had been sharply reduced, in addition to the disturbing visual experience of all the bridges that cut through the neighbourhood; in our interviews with A. M., T. S., A. D. and K. B they all pointed out the declining quality of life in the neighbourhood due to the new street interventions). Based on that, we concluded that enclaves in the form of gated communities have displayed better aesthetics and safety due to the presence of designated security and seclusion (self-contained worlds). However, enclaves as a by-product of road infrastructure did not display the same characteristics. On the contrary, they suffered from a worsened aesthetic value and decreased security due to the creation of ambiguous spaces (under bridges, non-lightened segments of streets, poor sidewalks and decreased community presence/ownership). 


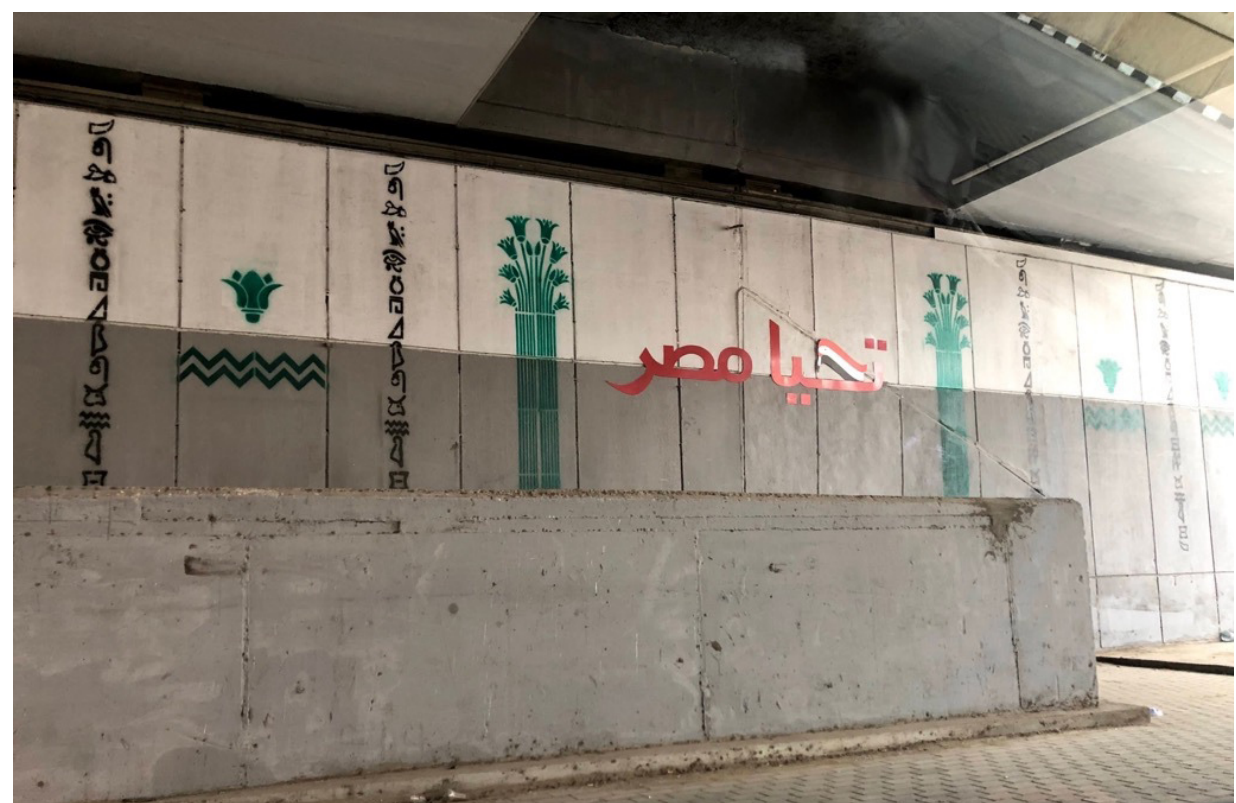

Figure 5. Tahya Masr ("Long Live Egypt"), a national slogan under a newly constructed bridge. Source: Safa Ashoub.

When we drove through the eastern neighbourhoods of Cairo, we noticed that the widening of roads and the construction of several flyovers in the neighbourhood taking place rapidly and without any prior announcements. Later, the survey respondents and interviews confirmed these observations. The reason was that in August 2018, several national transport-related projects were put in place and implemented rapidly (Al-Youm, 2018). Almost all of these projects were introduced suddenly, without any prior public information or engagement with the inhabitants. Afterwards, President El-Sisi declared that Heliopolis had to undergo important changes to become a transit corridor from and to the NAC ("Sisi inspects road, bridge constructions in Heliopolis," 2019), as shown in Figure 6.

As these projects ran, during the construction works, the neighbourhood had already begun to experience the enclaving. For example, in the sub-district of Almaza, the residents had had no easy entry to or exit from their neighbourhood during the construction of a bridge

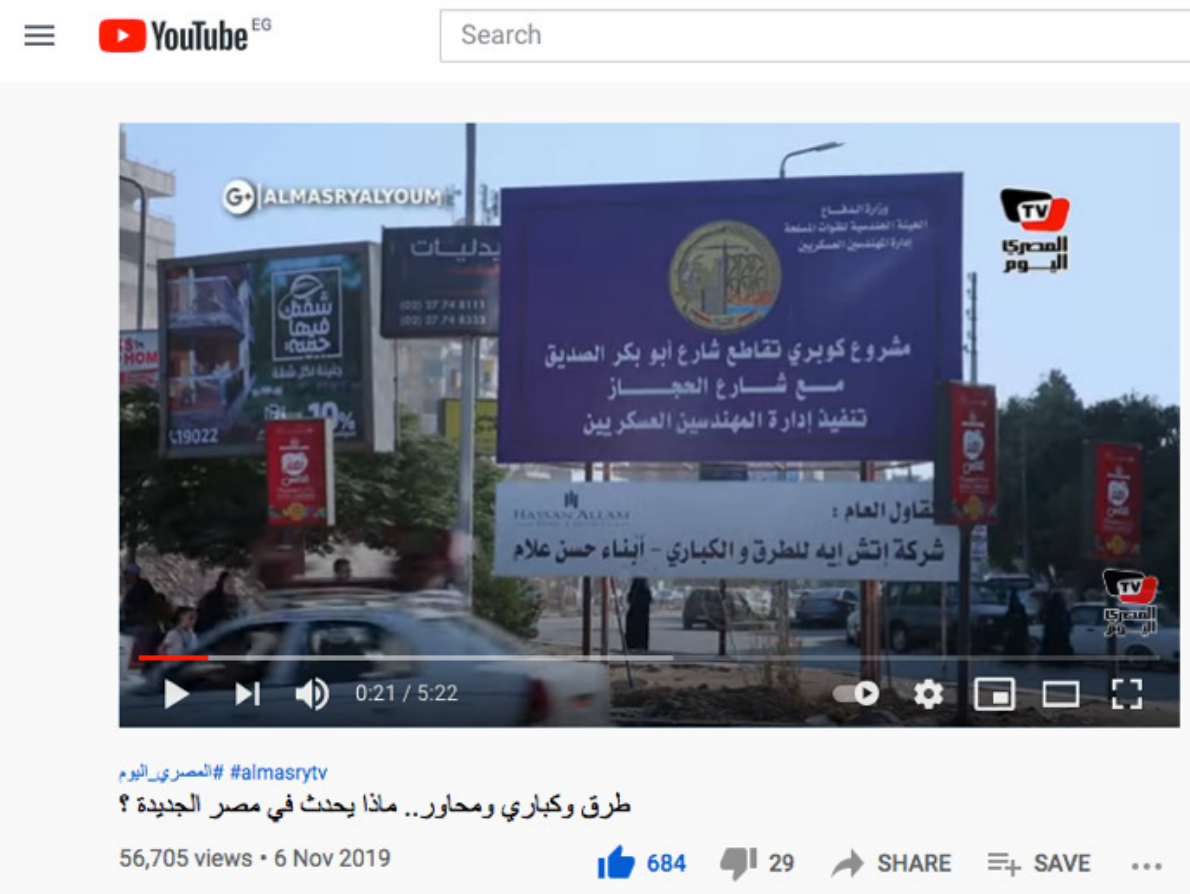

Figure 6. "Roads, axes and bridges...what is happening in Masr Al Gedida? Al-Masry Al-Youm newspaper covering the new roads, interchanges and bridges' construction in Heliopolis." Source: AlMasry AIYoum (2019). 
(Sidhom, 2019a). At that stage, many urbanists, journalists, and community activists voiced their concerns. We followed the social media pages of the neighbourhood and we recorded the following grievances. First was the issue of neglecting to inform the public, let alone opening a channel for participation; second, failing to plan alternative routes for traffic during the interventions; third, tree felling and the corresponding loss of distinctive greenery of Heliopolis (Agence France-Presse, 2020; Mounir, 2019) as well as elsewhere around the city as we observed later; fourth, the unconcealed disregard for community harmony and the destruction of the historic urban fabric, including irreplaceable villas and houses (Sidhom, 2019b); fifth, and most critically, the adverse effects that such interventions have produced in terms of road safety and reduced pedestrianism (Almoghazy, 2020; Shawkat, 2020). All these issues contributed to the loss of the quality of life in Heliopolis (nearly all respondents of the survey emphasised how the newly built roads were blatantly non-pedestrianfriendly and how that negatively impacted the quality of life of the neighbourhood as a result of such interventions). Consequently, we concluded that such infrastructure development was not meant to improve the lives of the citizens of the neighbourhood but rather to facilitate the movement to the new cities in the first place.

\subsection{New Roads and the Enclosure of the City}

As the current regime is planning to relocate the seat of government to the NAC (Figure 7), Heliopolis has become the centre and a symbol of the on-going policy of violent transformation.

While there might not be a publicly available document stating these intentions, the actions taken by the Egyptian government demonstrate that there is an on-going policy to readjust public transport projects that were originally destined to serve the residents of Cairo, especially the residents of, and commuters heading to, Heliopolis. Two stark examples of such a policy are the decimation of Heliopolis' trams and the cancellation of the Masaken Sheraton/Cairo Airport metro link.

\subsection{1. 'De-tramming' Heliopolis}

Trams were introduced to Cairo in the late 19th century as the city expanded beyond its walkable limits (Chalcraft, 2004; Gouda, 2015). They revolutionised travel all across Cairo and brought life and economic benefits to all the neighbourhoods that were within the trams' service area or nearby (Chalcraft, 2004).

Heliopolis, however, stood to benefit the most from the tram network (M. Farid \& Abdelhady, 2018; Gouda,

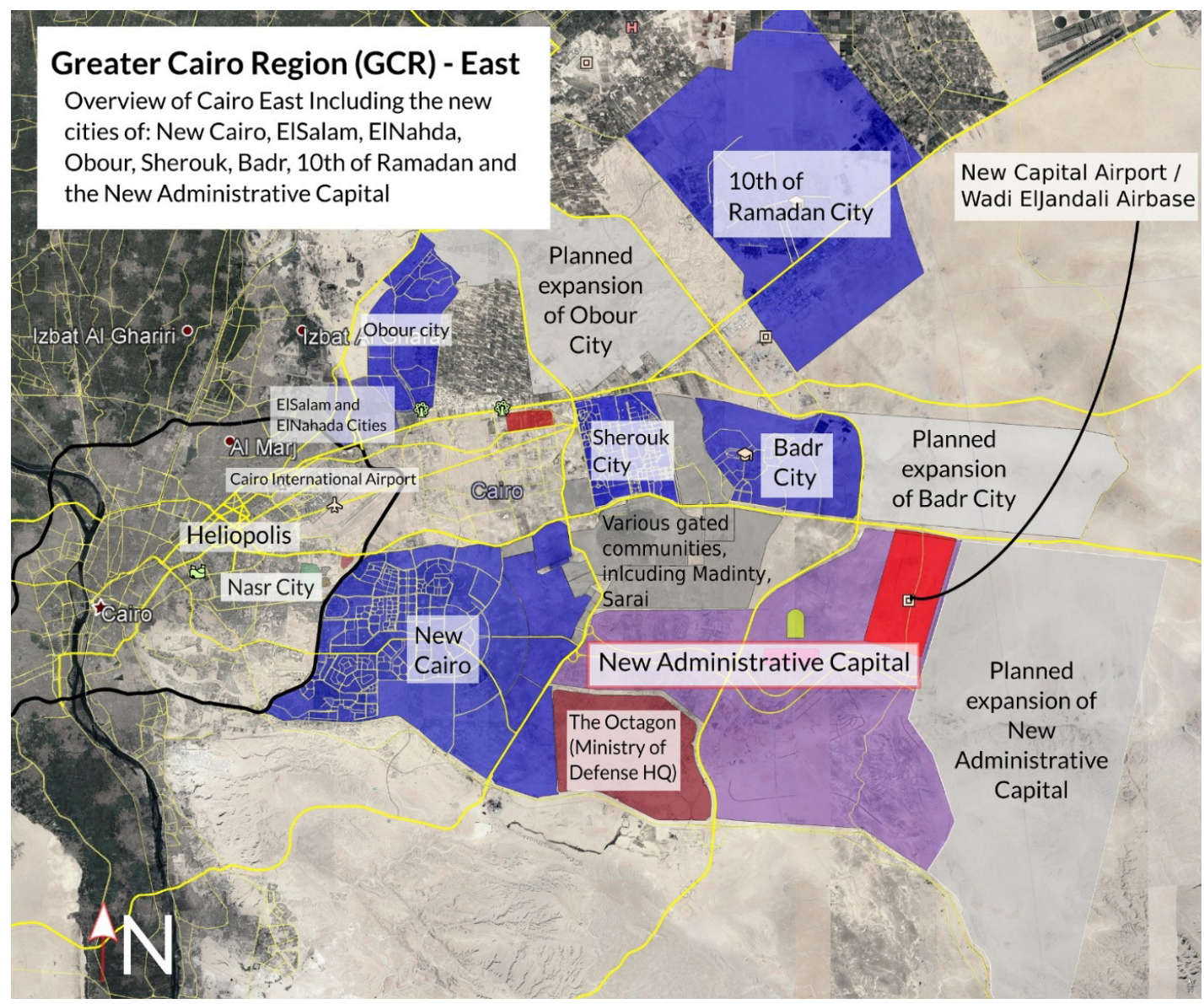

Figure 7. The eastern outskirts of the Greater Cairo metropolitan area with new desert cities. Map developed by M. W. ElKhateeb for this article based on Google Earth Pro based map. 
2015), since it used to be-when the first trams were inaugurated-the most remote part of town. Trams eventually became synonymous with Heliopolis and became an icon of local heritage and part of the neighbourhood (Gouda, 2015). Indeed, almost every other area in Cairo had the tramlines and trolleybuses removed by the Cairo Governorate starting in the 1980s (Bahgat et al., 1999), in favour of expanding roadways and giving priority to private cars (Mitric, 1994) and sometimes in favour of the underground metro (Bahgat et al., 1999). This era also witnessed the construction of major inner-urban highways such as the 6th of October Bridge and other road expansions (Mitric, 1994). Nevertheless, the Heliopolis trams were spared in the first wave of tram removals in Cairo, and despite the service's reduced reach and deteriorating service, trams remained a popular mode of transport and a cultural icon of Heliopolis (Gouda, 2015; Huzayyin \& Salem, 2013).

The most recent attempts to dismantle the remaining trams in Heliopolis surfaced during Galal El-Said's reign as the Governor of Cairo in mid-2014 (Cairo Governorate, 2020). However, when the Cairo Governorate announced that they intended to remove some of the tram tracks and to expand roadways in Heliopolis, the backlash was immediate and strong (Gouda, 2015; Salamah, 2014). Unlike the rest of Cairo, the residents of Heliopolis organised and formed local neighbourhood committees to try to prevent the trams from being dismantled (Heliopolis Heritage Initiative, 2017; Keshk, 2012). This was confirmed in an interview with A. M., who mentioned that saving the tram was one of the cornerstones of the Heliopolis Heritage Initiative's work as a grassroots entity. One of the few prominent local associations in the neighbourhood, the Heliopolis Heritage Initiative team, organised tours and other cultural activities to keep the trams alive and to raise awareness regarding the attempts to dismantle the remaining trams in Heliopolis (Ezzat, 2020; Gouda, 2015; Keshk, 2012).

By then, the Ministry of Transport had managed to secure funding from European Institutions to invest in and upgrade the existing tram network in Heliopolis (Barrow, 2016; Heliopolis Heritage Initiative, 2017). However, a few months later, the Governor of Cairo, El-Said, ordered the removal of an important intersection of tram tracks at Mahkama Square (Atef, 2015; ElTarawy, 2015; Felfel, 2016; Hamid, 2015) and the lone tramline connecting Heliopolis to Central Cairo (ElSharkawy, 2016; Gamal, 2016), effectively kneecapping the remaining tram network in Heliopolis and rendering it unusable (Hamid, 2015). El-Said was later selected to become the Minister of Transport, whereupon he almost immediately shelved the tram upgrade and renewal projects based on their 'high cost' (Ramzy, 2015), even though funding had been secured already and that Memorandum of Understanding had already been signed with European funding institutions (Barrow, 2016). Despite the new grim situation and the screeching halt of the tram upgrade project, some hope had remained that a future governor or minister of transport might restore the project and save the remaining trams of Heliopolis. However, all hopes were dashed when the remaining tram tracks were removed by the national and local governments (Figure 8) in a joint project to expand almost all of the major Heliopolis boulevards into urban highways (Almawkef AlMasry, 2020; M. Farid \& Abdelhady, 2018).

\section{Heliopolis Municipality Completely Removes Tram Line, Egypt}

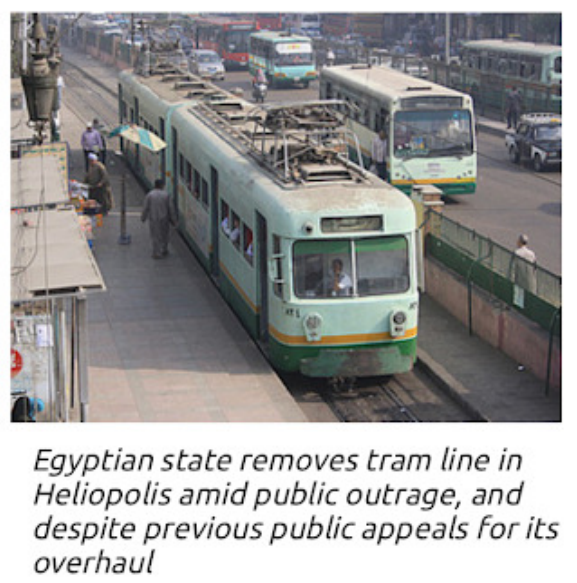

Figure 8. The complete removal of trams. Source: EJOLT (2019).

When the residents of Heliopolis forcefully objected to the new project and the tram removal, the government scrambled to organise a community-stakeholder discussion after the fact and tried to convince the residents of the project and its benefit (M. Farid \& Abdelhady, 2018). In addition, the Ministry of Environment engaged in the Et-Hadar Lel-Akhdar project ("Get Civilised/Ready for the Greenery"; see EIMiraghy, 2020), calling on people to plant trees and save the environment, ironically at the same time that the government was actively removing all of the green boulevards and trees from the heart of Heliopolis (F. Farid \& Harabech, 2020), as shown in Figure 9.

\subsubsection{The Heliopolis Metro Station Demoted}

The cancellation of the Cairo Airport Metro link, and how it was (gradually) cancelled, signalled the dwindling importance of Heliopolis, with the capital being physically relocated outside the reach of the masses. Previously, Heliopolis Square metro station was meant to serve as a 'central' metro station in East Cairo. Based on this plan, the National Authority for Tunnels built extra facilities and invested in extensive infrastructure to accommodate the expected passenger volumes 
descending on the Heliopolis Square metro station (Ragheb, 2020). However, in 2019, shortly after Kamel El-Wazir became the transport minister, the government announced that the Heliopolis-Cairo Airport metro link plan would be revisited and that it would possibly revert to the original plan, drafted by the Japan International Cooperation Agency (2002), diverting the airport metro link to go along the (southern) Adly Mansour branch and cancelling construction of the North Heliopolis/Masaken Sheraton route (Habashi, 2019). Then, a few months later and with minimal press coverage, El-Wazir announced that the extension of Line 3 to the airport would not take place and instead a Bus Rapid Transit route-including a 'shuttle bus' tunnel (Hussein, 2020) connecting to the airport-would be 'built' instead (Hassanen, 2020).

The cancellation of the Cairo Airport/Masaken Sheraton metro link has adversely impacted the residents of the northeast of Heliopolis and Masaken Sheraton, who no longer have any tram service (since the last remaining routes were removed) and the only remaining reliable, frequent and popular mode of public transport has been cancelled. That, in effect, has walled off the residents of Heliopolis and Masaken Sheraton into isolated enclaves surrounded by impassable urban highways, allowing only the better-off residents who own private vehicles to safely navigate out of their neighbourhood-a provocative situation, especially since only $11 \%$ of households in Greater Cairo own a private vehicle (El-Dorghamy et al., 2015).

$$
\text { ميدان الحجاز قبل وبعد التطوير.. }
$$

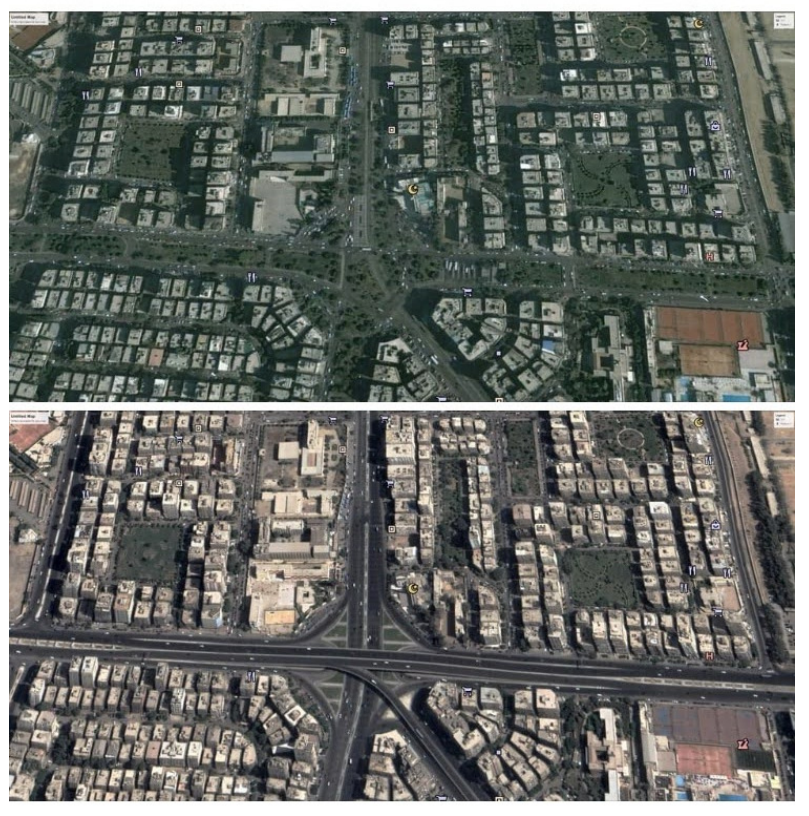

1 Comment 1 share

$$
0 \text { Like } \varnothing \text { Comment } \Rightarrow \text { Share }
$$

Figure 9. Al Hegaz Square before and after upgrading. Source: Hanna (2021).
Meanwhile, the Ministry of Transport has embarked on two new monorail projects: (1) the east route, starting from Cairo Stadium metro station in Nasr City, passing through New Cairo, and terminating at the NAC, and (2) the other route starting at Giza/Cairo University (on Line 3) and continuing west to 6th of October City (Figure 10). Transport officials ("Egypt to import coaches for Cairo Monorail project," 2020) were blunt about the monorail plans serving as a transit route connecting 6th of October City with the NAC via Line 3, meaning that the metro will now not only serve the residents of Cairo but also carry the mass of commuters travelling from 6th of October City to the NAC, adding burden to the already crowded metro system.

One just needs to look closely at a map of the newly built bridges and enormously widened (and rerouted) roads to notice that the former leafy boulevards that were a landmark of Heliopolis have been transformed into inner urban highways cutting through Heliopolis to allow increased vehicular traffic driving through the neighbourhood. Heliopolis' streets have been transformed into a massive highway interchange, connecting the Rod El-Farag Axis (a partly elevated highway connecting to 6th of October City, towards the west), Suez road (which directly leads to the NAC), and Ismailia road (which leads to the new cities and suburbs adjacent to the NAC, in the east).

Yet, paving the way to the New Capital is not the only explanation for such urban aggression. We also

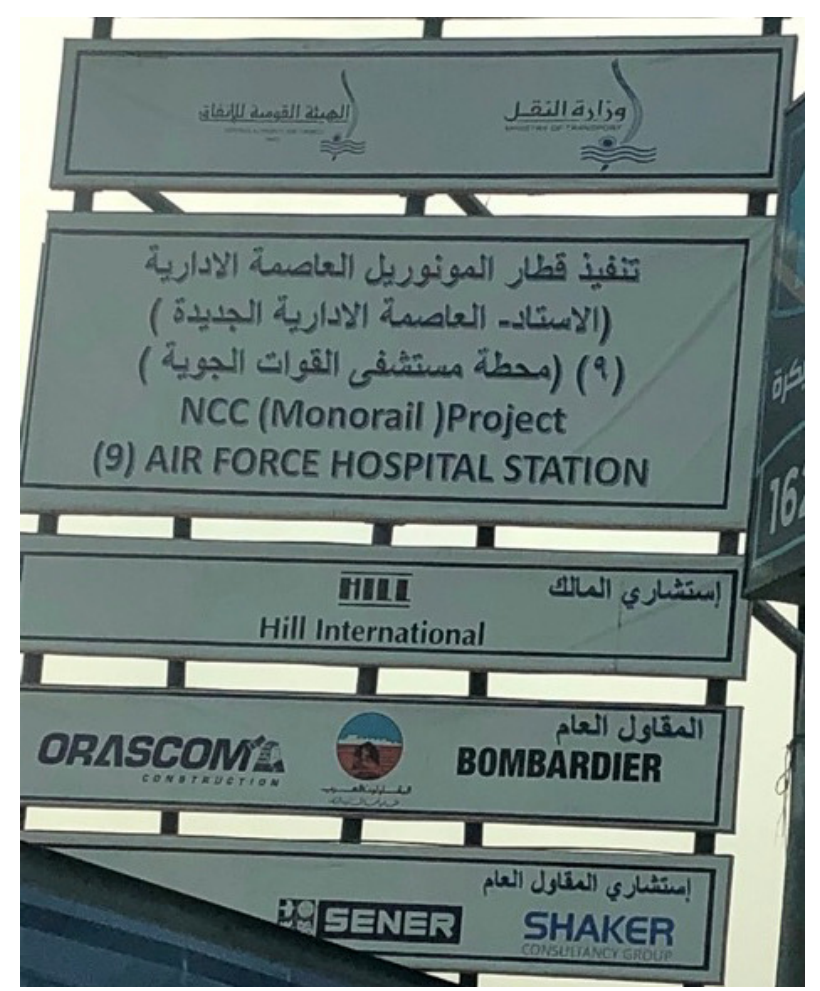

Figure 10. Monorail construction in New Cairo district. Note: Date: January 2021. Source: Safa Ashoub. 
observed deeper discussions over social media regarding an assumption that these unfavourable changes to the neighbourhood are meant to push residents away into potential new housing developments in the desert cities around the New Capital, as numerous Facebook posts of citizens pages stated. Even though we are careful about generating conclusions based on these statements, it seems that there is some truth to this one. Based on other interviews with the Heliopolis Heritage Initiative members, they all affirmed such juxtaposition. As such, we perceived the process of enclaving as dual in nature: one enclaving that occurs within the inner city and another in the gated communities of the desert cities. Both contribute to the overall reorganisation of the urban middle classes away from the centre and towards the periphery-and if they must remain, they should be strictly controlled within solid infrastructural barriers.

When one considers all the different examples discussed in this section, a link emerges between the political desire to create seamless urban highways that mainly aim to keep the flow of vehicular traffic unhindered, and the desire to quash any form of density or movement of the masses within the city. By decimating current public transport and limiting the prospects of such networks within neighbourhoods such as Heliopolis, and at the same time encouraging more individualised modes of transport (that only a well-off minority of Egyptians can afford), it becomes clear that these new highways become a 'wall of roads' that restrain and enclave the dense neighbourhoods of the city, making it even harder for pedestrians and public transit users to navigate the city; in turn, exacerbating the social fragmentation of the masses.

\section{Shifting Urban Centres; Disempowering Populations}

When we talk about Cairo, we know that social and spatial segregation are nothing new to the city (Adham, 2005; Caldeira, 1996), but perhaps they are currently assuming new forms. This is especially true when we observe the impacts of moving power to the periphery, as the NAC becomes the centre of official political activity in Cairo (Elmouelhi, 2019). This cannot happen without the purposeful action of fragmenting the sociospatial cohesion and creating rifts along the social, economic, and physical lines. The constraining of political freedoms and civil society becomes rooted in an urban order that reinforces a state of dissociation among its citizens, this observation was reiterated several times in the interviews (with K. B., A. M., M. H. and T. S.). In addition to the creation of a state of ambiguity, where no one knows or sees what is happening outside of policy circles. Eventually, this leads to the decline of the public sphere available for civil society's activities (Hasso, 2015; Zayani, 2012). It also leads to undermining the presence of an effective opposition, as collective action becomes grounds for suspicion, and the potential for conflict among different social segments is exacerbated due to the dissociative nature of the newly forged urban fabric (Hashemi, 2019).

This process of enclaving, we believe, is a new model for containing the city of Cairo and its (upper) middleclass residents, whereby the outcome is a city that is systematically dissected to create dissociation amongst the urban populations. Why the (upper) middle classes? Because they simply cannot be predicted or trusted, they can also mobilise resources, and they are well-educated with several accessibility privileges (Burris, 1986). During the 2011 uprising, a lot of the protests and sit-ins were staged by middle-class activists, even though they did not suffer political oppression like other groups (leftists or the Muslim Brotherhood, for example), nor did they struggle with their daily living (such as working-class citizens living in informal settlements or the old deteriorated core) (Sallam, 2013). However, another segment of the same class(es) stayed at home and watched the revolution from their living rooms. That brings us to the belief that targeting upper and middle classes is a post-ArabSpring tactic for control and containment. Each segment is dealt with using appropriate measures-a multiplicity of carrot-and-stick tricks to contain this wide and heterogeneous body of citizenry.

After the failure of the previous generations of New Cities (such as Sadat City, 10th of Ramadan) to achieve their target population goals (and to diffuse the urban agglomeration as well), it seems that the plan now is to disperse the rich among newly built, exclusive, gated communities within the new desert cities (Bufano, 2017; Sims, 2018). This urban diffusion (Adham, 2014) is designed to make such changes permanent, reducing the chances that the newly formed urban trends could be slowed down or reversed in the future, ultimately making the interconnectedness and permeability of city neighbourhoods significantly less attainable. In that sense, we are faced with two bulky urban forms, one that is enclaved within the boundaries of the old city, and another that is fenced across the desert cities within predetermined parameters. The seizure of the old city is completed via the development of wider and faster roads, flyovers, banners, billboards and concrete walls around certain potentially contentious spaces, sometimes even arbitrarily. All types of physical barriers are employed to reduce interconnectedness, permeability, and mobility. Segregation is complete when there is no longer a strong sense of community as what we gathered from the Heliopolis case.

In short, there are three particular intertwined aspects of the enclaving process that we would like to explicitly mention here: (1) the process of enclaving as a political tool for control, (2) the explicit targeting of (upper) middle-class citizens-either through diffusion into new desert cities or through by walling them off and surrounding them with barricaded spaces-and finally (3) the issue of expanding streets to appear as a form of infrastructure upgrading when in reality it is a measure to ensure the state's domination over territory. 


\section{Conclusion}

This article is an attempt to conceptualise urban enclaving as a process that is systematically woven to produce a new spatial reality. In our view, enclaving is not only the creation of gated communities and the like; it is rather a process of controlling the current built environment through the establishment of roads, highways, bridges and other types of physical infrastructure that obstruct access and mobility, or otherwise limit and control the free movement or assembly of citizens. These inner-city enclaves also perpetuate the belief that living in a securitised environment is better and safer, especially as private real estate developers promote distant gated communities out in the desert for the wealthy.

This spatial and socio-economic contextual analysis is the result of investigating the nature and the processes that have produced the current city, with the orchestration of urban and the political agendas of the post Arab Spring, ruling regime. In answering our hypothesis, we have concluded that the new road infrastructure is part of a larger scheme that seeks to dissolve the old city using socio-spatial segregation tools, with the ultimate objective of controlling and developing the inner and outer city zones as politically uncontentious spaces. This happens as rapid planning processes that justify its actions with the need to upgrade and achieve an improved urban environment.

Since Cairo was the capital of the Arab Spring and has been the locus for collective mobilisations, we stipulate that the magnitude of the city and its intricacies have posed a major challenge to urban planners and politicians. One bi-product of the revolution was a counter-revolution that instrumentalised the discourse of development to deploy state-monopolised violence in the urban space. As a result, this unprecedented urban aggression means that populations will have to succumb to a new socio-spatial-political order-an order that sees itself beyond questioning or legitimisation.

\section{Acknowledgments}

The first author would like to express her gratitude to her primary supervisor, Professor Jörg Stollmann, who guided her throughout this project. We would also like to thank our friends and family who supported us and offered deep insight into the study. Namely, we would like to thank Salma Khamis for her relentless support and guidance on methods, Elaf Raslan for her initial edits and Frieda Sapel for her proofreading. We are also very thankful to our friends and colleagues for their intuitions about Cairo. We acknowledge support by the German Research Foundation and the Open Access Publication Fund of TU Berlin.

\section{Conflict of Interests}

The authors declare no conflict of interests.

\section{References}

Abaza, M. (2012). Cyberspace and the changing face of protest and public culture in Egypt. In H. Wimmen, L. Al-Zubaidi, \& L. Sadiki (Eds.), Democratic transition in the Middle East: Unmaking power (1st ed., pp. 86-108). London: Routledge.

Abaza, M. (2014). Post January Revolution Cairo: Urban wars and the reshaping of public space. Theory, Culture \& Society, 31(7/8), 163-183. https://doi.org/ $10.1177 / 0263276414549264$

Abaza, M. (2020). The global war on terror, military urbanism and neoliberal dystopias. The Arab Spring and Europe. In F. Sabaté (Ed.), Ciutats mediterrànies: L'espai i el territori [Mediterranean towns: Space and territory] (pp. 247-254). Barcelona: Institut d'Estudis Catalans. Retrieved from https://publicacions.iec. cat/repository/pdf/00000291/00000002.pdf

Abu-Lughod, J. L., \& AlSayyad, N. (2020). Cairo. Britannica Online Encyclopaedia. Retrieved from https:// www.britannica.com/place/Cairo

Adham, K. (2005). Globalization, neoliberalism, and new spaces of capital in Cairo. Traditional Dwellings and Settlements Review, 17(1). Retrieved from https:// www.jstor.org/stable/41758302

Adham, K. (2014). Modes of urban diffusion-Culture, politics and the impact of the recent urban developments in the Arabian Gulf cities on Cairo's Vision 2050. In B. Krawietz, K. Bromber, \& S. Wippel (Eds.), Under construction: Logics of urbanism in the Gulf region (pp. 233-245). Farnham: Ashgate.

Agence France-Presse. (2020, February 11). Cairo's green lung razed for roads to new desert capital. Ahram Online. Retrieved from english.ahram.org.eg/ NewsPrint/363273.aspx1/3

Al-Youm, A. (2018, July 3). Sisi announces transport network development plan. Egypt Independent. Retrieved from https://egyptindependent.com/sisiannounces-transport-network-development-plan/

AIMasry AlYoum. (2019, November 6). Turuq wakibari wamuhawr...Madha yahduth fi misr aljadida? [Roads, axes and bridges... What is happening in Masr Al Gedida?] [Video file]. Retrieved from https://www. youtube.com/watch?v=jaCznHonp_U

Almawkef AlMasry. (2020, February 4). Tatweer masr elgedida: A's'ilah tantazer i'gaba [Development of Heliopolis: Questions awaiting answers; Facebook status update]. Retrieved from https://m.facebook. com/almawkef.almasry/posts/2301411949958689

Almoghazy, A. (2020). New roads, bad connections: How new road projects impact the right to the city. Alternative Policy Solutions. Retrieved from https://aps.aucegypt.edu/en/articles/608/newroads-bad-connections-how-new-road-projectsimpact-the-right-to-the-city

AlSayyad, N., \& Guvenc, M. (2015). Virtual Uprisings: On the Interaction of New Social Media, Traditional Media Coverage and Urban Space during the 'Arab 
Spring.' Urban Studies, 52(11), 2018-2034. https:// doi.org/10.1177/0042098013505881

Atef, S. (2015, October 7). Rafe' Kodban Tram ElMatariya lel Siyola elmororia [Removing ElMatariya tram tracks for increased traffic flow]. AlMasryalyoum. Retrieved from https://www.almasryalyoum.com/ news/details/822877

Atkinson, R., \& Ho, H.-K. (2019). Segregation and the super-rich: Enclaves, networks and mobilities. In S. Musterd (Ed.), Handbook of urban segregation (pp. 289-305). London: Edward Elgar.

Bahgat, P. D. A., El-Tony, D. F., El-Mahdi, D. R., Boshra, D. E., Abbas, D. K., Fattah, D. A., . . White, P. P. (1999). Impacts of the Cairo metro. Cairo and London: Egyptian National Institute of Transport and the University of Westminster.

Barrow, K. (2016, May 11). EBRD to finance Cairo tram revival. International Railway Journal. Retrieved from https://www.railjournal.com/passenger/lightrail/ebrd-to-finance-cairo-tram-revival

Baur, N. (2019). Linearity vs. circularity? on some common misconceptions on the differences in the research process in qualitative and quantitative research. Frontiers in Education, 4. https://doi.org/ 10.3389/feduc.2019.00053

Bhan, G. (2019). Notes on a Southern urban practice. Environment and Urbanization, 31(2), 639-654. https://doi.org/10.1177/0956247818815792

Bufano, M. (2017). The mirage: Dreams of utopia in the deserts of Egypt and Greater Cairo's chaotic reality (Unpublished Doctoral dissertation). American University in Cairo, Egypt. Retrieved from https://fount. aucegypt.edu/etds/653

Burris, V. (1986). The discovery of the new middle class. Theory and Society, 15(3). https://doi.org/10.1007/ BF00172232

Cairo Governorate. (2020). List of former Cairo Governors. Cairo.gov. Retrieved from http://www.cairo. gov.eg/en/Pages/ExGovernor.aspx?SubmID=100

Caldeira, T. P. R. (1996). Fortified enclaves: The new urban segregation. Public Culture, 8(2), 303-328. https://doi.org/0899-236319610802-0006

Calvet, M. S. (2016). The greening of neoliberal urbanism in Santiago de Chile: Urbanisation by green enclaves and the production of a new socio-nature in Chicureo (Unpublished Doctoral dissertation). University College London, UK.

Chalcraft, J. T. (2004). The striking cabbies of Cairo and other stories: Crafts and guilds in Egypt, 1863-1914. Albany, NY: State University of New York Press. Retrieved from https://books.google.de/books?id= b_w97t_BCJEC

Daher, R. F. (2013). Neoliberal urban transformations in the Arab city. Environnement Urbain/Urban Environment, 7, 99-115. Retrieved from http://journals. openedition.org/eue/411

Egypt to import coaches for Cairo Monorail project, starting July 2021. (2020, October 4). Egypt Independent.
Retrieved from https://egyptindependent.com/ egypt-to-import-coaches-for-cairo-monorail-projectstarting-july-2021

EJOLT. (2019, July 4). Heliopolis Municipality completely removes tram line, Egypt. EJAtlas. Retrieved from https://ejatlas.org/conflict/decommissioning-ofthe-heliopolis-neighbourhood-tram-line1

Elden, S. (2007). There is a politics of space because space is political: Henri Lefebvre and the production of space. Radical Philosophy Review, 10(2), 101-116. https://doi.org/10.5840/radphilrev20071022

El-Dorghamy, A., Allam, H., Al-Abyad, A., \& Gasnier, M. (2015). Fuel economy and CO2 emissions of light-duty vehicles in Egypt. Vienna: Centre for Environment and Development in the Arab Region and Europe.

ElMiraghy, D. (2020, October 30). Ethadar lel akhadar mobadarah ri'asia lewakf eltadahwor elbi'i a'br eltashgiir wa tadwir elmokhalafat [Ethadar lel Akhadar: A Presidential initiative to halt environmental degradation via afforestation and recycling]. Ahram Online. Retrieved from http://gate.ahram.org. eg/News/2504578.aspx

Elmouelhi, H. (2019). New administrative capital in Cairo: Power, urban development vs. social injusticeAn Egyptian model of neoliberalism. In A. AlHamarneh, J. Margraff, \& N. Scharfenort (Eds.), Neoliberale urbanisierung [Neoliberal urbanization] (pp. 215-254). Bielefeld: transcript Verlag. https:// doi.org/10.14361/9783839437803-007

EISharkawy, A. (2016, September 1). Ra'yes Hai'at elNakl elA'am: Bid' izalet kodban tram Masr ElGadida min Roxy ila Ramses [Head of CTA: Removal of tram tracks from Roxy to Ramses begins]. Ahram Online. Retrieved from http://gate.ahram.org.eg/News/ 1233621.aspx

ElTarawy, S. (2015, October 7). Belsewar: Mohafez ElKahira yo'elen khitat tatwier Tram EIMatarya [In Photos: Cairo Governor announces tram development plan]. Al-Wafd. Retrieved from shorturl.at/rDNU9

Ezzat, D. (2020, June 19). Documenting Heliopolis. Ahram Online. Retrieved from http://english.ahram. org.eg/NewsPrint/372323.aspx

Farid, M., \& Abdelhady, O. (2018). Assessment Heliopolis heritage suburb against sustainable conservation. Resourceedings, 1(2), 198. https://doi.org/10.21625/ resourceedings.v1i2.336

Farid, F., \& Harabech, H. (2020, February 11). Cairo's green lung razed for roads to new desert capital. The Jakarta Post. Retrieved from https://www. thejakartapost.com/news/2020/02/11/cairos-greenlung-razed-for-roads-to-new-desert-capital.html

Frearson, A. (2015, March 20). SOM unveils vision of new Egyptian capital for seven million people. Dezeen. Retrieved from https://www.dezeen.com/2015/03/ 20/som-new-capital-city-cario-egypt-seven-millionpeople

Felfel, A. (2016, November 19). Metro Masr elGadida 'Shaheed A'ala Kazeb elHokoma,' A'sasaho ElBaron 
wa Damarho ElSaid. Ezalt Kodban Mostafa EINahas wa AlMerghani wa elKitar ElSaree' wa Kolyet ElBanat 'Fankoush' [Heliopolis metro: A witness on the government's lies. Built by the Baron and destroyed by EISaid, removing the tram tracks from Mostafa EINahas and AlMerghani streets: The high-speed tram of Kolyet ElBanat and Ramses is 'fake or nonexistent']. Vetogate. Retrieved from shorturl.at/aGKL2

Flahive, R. (2018, July 17). Regime-security urbanism: Cairo 2050 \& beyond. Jadaliyya. Retrieved from https://www.jadaliyya.com/Details/37753

Gamal, A. (2016, September 1). ElNakl ElA'am: Tayseer Autobisat bi-khat sayer tram Ramses-Roxy ba'ad rafe' elkodban [Cairo transit authority: Buses to run on former Ramses-Roxy tram route after removal of tracks]. Sada ElBalad. Retrieved from https://www.elbalad. news/2387803

General Organisation of Physical Planning and Ministry of Housing. (2010). Cairo Vision 2050: The strategic urban development plan of Greater Cairo region [PowerPoint presentation].

Gouda, S. M. (2015). Towards a sustainable preservation approach to Egyptian heritage neighborhoods (Unpublished Doctoral dissertation). Technical University of Dortmund, Germany.

Habashi, R. (2019, February 11). Khtet elNakl litawfeer 9 millare genih: Ta'deel mashrou' waslet metro Matar ElKhaira [Ministry of Transport's plan to save 9 billion EGP: Amending the Cairo airport metro link]. Youm7. Retrieved from shorturl.at/htN18

Hamid, M. (2015, October 22). A'malit khaskhasit elnakl elA'am tabd' bi-Ilgha' elTram [Operation public transport privatization starts with canceling the trams]. ElBawaba News. Retrieved from https:// www.albawabhnews.com/1563382

Hanna, M. [Michel]. (2021, April 22). Midan Alhegaz, wahid min 'ajmal miadin misr algadida, qabl altatwir wabiedaltatwir [Hegaz Square, one of the most beautiful squares in Heliopolis, before and after development]. [Facebook status update]. Retrieved from https://www.facebook.com/michelhn/posts/ 10158963736316226

Harvey, D. (2005). A brief history of neoliberalism. Oxford: Oxford University Press.

Hashemi, M. (2019). Embedded enclaves: Cultural mimicry and urban social exclusion in Iran. International Journal of Urban and Regional Research, 43(5). https://doi.org/10.1111/1468-2427.12799

Hassanen, A. (2020, March 11). Heta Mn Europa: Hakaza satakoon matet Adly Mansour [A piece of Europe and a commercial area: This is how Adly Mansour station is going to look like]. Masralarabia. Retrieved from shorturl.at/ahisQ

Hasso, F. S. (2015). (Civil) and the limits of politics in revolutionary Egypt. Comparative Studies of South Asia, Africa and the Middle East, 35(3), 605-621. https:// doi.org/10.1215/1089201X-3426445

Heliopolis Heritage Initiative. (2017, April 19). A'am kamel a'ala bidayet wosol elmosa'adat elmalia liTatweer Tram/Metro Masr ElGadida [One year since the arrival of the financial aid to develop Heliopolis' tram/metro; Facebook status update]. Retrieved website https://www.facebook.com/Heliopolis Heritagelnitiative/photos/a.423060991079531/ 1478909725494647

How Cairo's Heliopolis heritage managed to remain uncovered. (2021, February 15). Al-Monitor. Retrieved from https://www.al-monitor.com/pulse/ originals/2021/02/egypt-basilica-bridge-landscapeconstruction.html

Hussein, H. (2020, July 11). Wazir ElNakl: Ala'mal a'la nafak mn mahtet Adly Mansour ila mabna elrokab elra2isi biMatar ElKahira [Minister of Transport: We are working on a tunnel connecting from Adly Mansour to a main passenger terminal at Cairo Airport]. Sada ElBalad. Retrieved from https://www.elbalad. news/4402549

Huzayyin, A. S., \& Salem, H. (2013). Analysis of thirty years evolution of urban growth, transport demand and supply, energy consumption, greenhouse and pollutants emissions in Greater Cairo. Research in Transportation Economics, 40(1), 104-115. https:// doi.org/10.1016/j.retrec.2012.06.035

Japan International Cooperation Agency. (2002). Transportation master plan and feasibility study of urban transport projects in Greater Cairo region in the Arab Republic of Egypt. Phase 1: Final report. Tokyo: Pacific Consultantas International. Retrieved from https:// books.google.de/books?id=xu28ZwEACAAJ

Keshk, F. (2012, May 9). Independent heritage initiatives: A first step to linking communities to their own histories. Egypt Independent. Retrieved from https://egyptindependent.com/independentheritage-initiatives-first-step-link-communitiestheir-own-histories

Kingsley, P. (2015, March 16). A new New Cairo: Egypt plans $£ 30$ bn purpose built capital in desert. The Guardian. Retrieved from https://www.theguardian. com/cities/2015/mar/16/new-cairo-egypt-planscapital-city-desert

Lefebvre, H., Elden, S., \& Brenner, N. (2009). State, space, world selected essays. Minneapolis, MN: University of Minnesota Press.

Lehdonvirta, V., Oksanen, A., Räsänen, P., \& Blank, G. (2020). Social media, web, and panel surveysUsing non-probability samples in social and policy research. P\&I: Policy \& Internet, 13(1). https://doi. org/10.1002/poi3.238

Lindsey, U. (2017). The anti-Cairo. Places Journal. https:// doi.org/10.22269/170314

Löw, M., \& Goodwin, D. (2016). The sociology of space: Materiality, social structures, and action. New York, NY: Palgrave Macmillan.

Luger, J. (2016). Comparative urbanism and the authoritarian city: Complexity, context, and strategicrelationality (Working Paper). Northumbria: Uni- 
versity of Northumbria. https://doi.org/10.13140/ RG.2.1.2188.0567

Mitric, S. (1994). Urban transport strategy for Cairo: Advice and dissent. Transportation Research Board, 1994(1441), 127-133. Retrieved from http:// onlinepubs.trb.org/Onlinepubs/trr/1994/1441/1441015.pdf

Mounir, C. (2019, August 7). Trees razed for bridge construction in Heliopolis. Egypt Independent. Retrieved from https://www.egyptindependent.com/treesrazed-for-bridge-construction-in-heliopolis

Nielsen, M., Sumich, J., \& Bertelsen, B. E. (2020). Enclaving: Spatial detachment as an aesthetics of imagination in an urban sub-Saharan African context. Urban Studies. https://doi.org/10.1177/ 0042098020916095

Perry, R. W. (2000). City of walls: A discussion with Teresa Caldeira. Political and Legal Anthropology Review, 23(1), 122-137.

Presidency. (n.d). Al-Ittihadiya palace [Heliopolis palace]. Presidency. Retrieved from https://bit.ly/3viywZz

Pulla, V. (2014). Grounded theory approach in social research. Space and Culture, 2(3), 14-23. https://doi. org/10.20896/saci.v2i3.93

Qutoshi, S. B. (2015). Auto-ethnography: A transformative research paradigm. Dhaulagiri Journal of Sociology and Anthropology, 9, 138-164. https://doi.org/ 10.3126/dsaj.v9i0.14027

Ragheb, K. (2020, March 8). ElNakl: Takrr tagmeed rabt elmetro biMatar ElKhaira wa istbdaluh beShuttle Bus [Ministry of Transport decides to freeze link to Cairo airport, replaces with 'Shuttle Bus']. Almasryalyoum. Retrieved from https://www.almasryalyoum. com/news/details/2006112

Ramzy, A. (2015, December 13). Tram Masr ElGadida yeowagih shabah alikhtifa' wa kitar elmatarya lan yao'd [Heliopolis Tram faces danger of disappearing, and Mataryia train is gone with no return]. Almal. Retrieved from shorturl.at/IpsLZ

Reeve, C. (2011, July 29). What ever happened to Cairo 2050? Egypt Independent. Retrieved from https://egyptindependent.com/what-everhappened-cairo-2050

Rennick, S. A. (2013). Contested meanings in the Egyptian revolution. Socio, 2, 81-98. https://doi.org/ 10.4000/socio.408

Robinson, J., \& Roy, A. (2016). Debate on global urbanisms and the nature of urban theory: Debates \& developments. International Journal of Urban and Regional Research, 40(1), 181-186. https://doi.org/ 10.1111/1468-2427.12272

Roitman, S. (2010). Gated communities: Definitions, causes and consequences. Proceedings of the Institution of Civil Engineers-Urban Design and Planning, 163(1), 31-38. https://doi.org/10.1680/udap. 2010.163.1.31

Roll, S. (2014). Al-Sisi's development visions: Projects and power in Egypt (SWP Comment 2014/C). Berlin: German Institute for International and Security Affairs.
Salamah, Y. (2014, September 20). Tram Masr ElGididah EIMahta ElAkhiera [Heliopolis tram: Last stop]. Masrawy. Retrieved from shorturl.at/jnET5

Sallam, H. (2013). The Egyptian Revolution and the politics of histories. PS: Political Science \& Politics, 46(2), 248-258. https://doi.org/10.1017/S104909 6513000231

Saunders, P. (1986). Social theory and the urban question (2nd ed.). London and New York, NY: Routledge.

Shawkat, Y. (2020). Cairo's new roads: An assault on pedestrians and mass transit. Alternative Policy Solutions. Retrieved from http://aps.aucegypt.edu/ en/commentary-post/cairos-new-roads-an-assaulton-pedestrians-and-mass-transit

Sidhom, Y. (2019a, September 15). Almaza residents under siege. Watani International. Retrieved from https://en.wataninet.com/opinion/editorial/almazaresidents-under-siege/30594

Sidhom, Y. (2019b, December 4). Heliopolis sacrificed for new capital? Watani International. Retrieved from https://en.wataninet.com/opinion/editorial/ heliopolis-sacrificed-for-new-capital/31276

Sims, D. (2012). Understanding Cairo: The logic of a city out of control. London: I.B. Tauris.

Sims, D. (2018). Egypt's desert dreams: Development or disaster. Cairo: American University in Cairo Press.

Sisi inspects road, bridge constructions in Heliopolis. (2019, November 8). Egypt Today. Retrieved from https://www.egypttoday.com/Article/1/77583/ Pics-Sisi-inspects-road-bridge-constructions-inHeliopolis

Sumich, J. (2016). The uncertainty of prosperity: Dependence and the politics of middle-class privilege in Maputo. Ethnos, 81(5), 821-841. https://doi.org/ 10.1080/00141844.2014.1002860

Suri, H. (2011). Purposeful sampling in qualitative research synthesis. Qualitative Research Journal, 11(2), 63-75. https://doi.org/10.3316/QRJ1102063

Tadamun. (2014). Coming up short: Egyptian government approaches to informal areas. Tadamun. Retrieved from http://www.tadamun.co/comingshort-government-approaches-informal-areas/ ?lang=en\#.X8Fcxqoza8o

Throne, R. (2012). Practitioner research in doctoral education. Dubuque, IA: Kendall Hunt.

Wang, K., \& He, S. (2019). Enclave urbanism. In A. M. Orum (Ed.), The Wiley Blackwell encyclopedia of urban and regional studies. https://doi.org/10.1002/ 9781118568446.eurs0089

Zaineldine, A. (2020). In pictures: A tribute to Heliopolis, one of Cairo's earliest suburbs. Egyptian Streets. Retrieved from https://egyptianstreets.com/2020/ 01/23/in-pictures-a-tribute-to-heliopolis-one-ofcairos-earliest-suburbs

Zayani, M. (2012). Civil society and democratic change in the Arab World: Promises and impediments. Comparative Studies of South Asia, Africa and the Middle East, 32(3), 674-685. https://doi.org/10.1215/ 1089201X-1891651 


\section{COGITATIO}

\section{About the Authors}

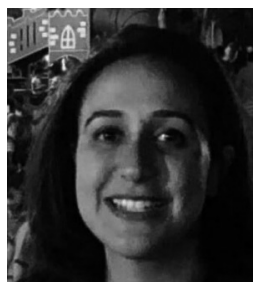

Safa H. Ashoub is an Interdisciplinary Researcher, a Political Scientist, and an Urbanist. She holds a double master's in International Cooperation and Urban Development (Germany/Italy) and a master's degree in Politics (UK). She has worked in international development for more than 12 years in the fields of participatory development, urban governance, institutional capacity development and climate change adaptation. She is currently a PhD Candidate at the Chair for Urban Design and Urbanisation, TU Berlin. Her research focuses on urban politics and qualitative social research.

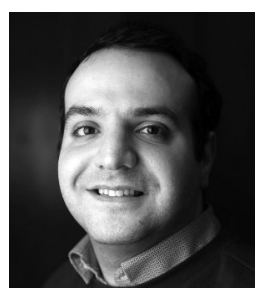

Mohamed W. ElKhateeb is a Sustainable Urban Mobility Researcher and Enthusiast. He holds an MSc. degree in Environmental Governance from the University of Freiburg. He also has a long experience working in NGOs in Egypt and is currently a volunteer member of the Supervisory Board of Greenpeace Middle East and North Africa (GP MENA). 